\title{
Investigation of aerodynamic evaluation in female patients undergoing thyroidectomy*
}

\author{
Young Ae Kang ${ }^{1} \cdot$ In Sun Kwon ${ }^{2} \cdot$ Ho-Ryun Won ${ }^{1} \cdot$ Jae Won Chang ${ }^{1} \cdot$ Bon Seok Koo ${ }^{1, * *}$ \\ ${ }^{1}$ Department of Otolaryngology-Head and Neck Surgery, Chungnam National University Hospital, Daejeon, Korea \\ ${ }^{2}$ Clinical Trials Center, Chungnam National University Hospital, Daejeon, Korea
}

\begin{abstract}
Breathing is the voice's driving force and also acts as a regulator of larynx function and efficiency. Respiratory distress is a side effect of general anesthesia in thyroid surgery. Therefore, this study's objective was to provide practical and complementary information for voice recovery after thyroid surgery, based on aerodynamic evaluation pre- and post-thyroidectomy. From May 2014 to July 2015, aerodynamic evaluations were performed on 34 female patients diagnosed with thyroid papillary cancer one week before surgery (PRE), one month after surgery (P1), and three months after surgery (P3). The Phonatory Aerodynamic System (model 6600, KayPENTAX, USA) was employed for this purpose, and a total of 29 analysis parameters were selected. The results showed statistically significant differences in peak expiratory airflow $(p=0.004)$, mean pitch $(p<0.01)$, expiration airflow duration $(p=0.001)$, and expiratory volume $(p=0.018)$, based on time factors. In the comparison of time factors, peak expiratory airflow and mean pitch parameters were different in PRE-P1 and PRE-P3. Expiration airflow duration and expiratory volume parameters were different in PRE-P3 and P1-P3. The interaction effect of time and surgical range was significant only for expiratory volume $(p=0.024)$. Female patients who undergo thyroidectomy require post-operative breathing training, and exhalation improvement is considered to reflect a positive lifestyle after surgery.
\end{abstract}

Keywords: thyroidectomy, aerodynamic evaluation, female

\section{1. 서론}

갑상선결절의 일부(7\%-15\%)가 갑상선 암이며 2000년대 들 어 고해상도 초음파 기기가 임상에 널리 쓰이게 되면서 전 세계 적으로 갑상선암 빈도가 빠른 속도로 증가하고 있다(Yi et al., 2016). 갑상선 수술 후 반회후두신경 신경손상으로 음성변화를
보이는 경우도 있지만 반회후두신경이 보존되었다 하더라도 음역감소, 발성 피로, 기본주파수 하강, 쉰 목소리 등 객관적 및 주관적 음성 사용 문제가 수개월 간 지속될 수 있다(Choi et al., 2010; Hong, 2014; Kang \& Koo, 2015; Park \& Do, 2015). 많은 선 행연구에서 갑상선 수술 후 신경손상 없는 음성 변화에 대한 원 인가설로 기관 삽관에 따른 손상, 후두로의 혈액 순환장애, 피

\footnotetext{
* This work was supported by the research fund of Chungnam National University.

** bskoo515@cnu.co.kr, Corresponding author

Received 27 April 2020; Revised 18 May 2020; Accepted 18 May 2020

(C) Copyright 2020 Korean Society of Speech Sciences. This is an Open-Access article distributed under the terms of the Creative Commons Attribution NonCommercial License (http://creativecommons.org/licenses/by-nc/4.0) which permits unrestricted non-commercial use, distribution, and reproduction in any medium, provided the original work is properly cited.
} 
대근(strap muscle) 및 후두기관의 유착에 의한 상-하운동장애, 윤상갑상근 및 경부근의 손상과 치유 과정에서 섬유화(Hong, 2014), 피대근 눌림 및 기관 삽관 및 정맥계 손상에 따른 성대부 종, 수술 중 의인성 신경외상, 심인성 발성불능, 목 질량 변화로 부적응 발성, 갑상선 기능저하 같은 내분비 변화 등을 들고 있 다(Choi, 2010; Kang \& Koo et al., 2015).

음성은 폐에서 올라오는 공기를 주원료로 생성되는 물리적 결과물이기에 음성을 논하기 위해서는 발동부인 공기흐름과 조절을 살펴볼 필요가 있다. 술자마다 조금씩 차이가 있겠으나 한쪽 갑상선 엽을 절제할 경우(lobectomy) 전신마취 시간이 보 통 1시간 소요되고 전절제할 경우(total thyroidectomy) 더 많은 시간이 필요하다. 이렇게 전신마취 시간이 길어질수록 폐 기능 저하를 겪게 되므로 갑상선수술 환자의 공기역학 검사를 추적 관찰하여 수술 후 언제 호흡기능이 회복되는지 확인하여 음성 재활에 기본 정보로 활용할 필요가 있다.

Shin et al.(2014)에서는 갑상선절제술 받은 21명(남:여, 4:17) 을 대상으로 술전-술후1주-술후6주에 걸쳐 공기역학 검사를 실 시한 결과, 술후1주에 평균 파워 값이 증가하다 술후6주에 감소 하였고 평균효율과 최대발성지속시간은 상승하여 회복경향을 보고했다. 하지만 본 선행연구는 술 후 추적관찰 시기를 술후6 주로 삼았기에 일반적인 임상에서 환자 회복기 소견인 술후 3 개 월보다 짧아 아쉬움이 있다.

Lee et al.(2015)에서는 갑상선절제술을 받은 20명(남:여, 2:18) 을 음성불편 유무에 따라 각각 10 명씩 나누어 술전-술후2주-술 후3개월에 걸쳐 공기역학 검사결과를 비교하였다. 두 군 간 폐 활량, 평균 호기류율에 차이는 없었으나, 최대발성지속시간과 발성역치 압력은 술후 각각 감소-증가를 보여 통계적으로 유의 미한 차이를 보고했다. 또한 모든 대상자에게 호흡훈련 활동의 음성치료를 2주간 2회기를 실시하여 치료 후 발성역치압력의 감소와 최대연장발성시간의 증가를 확인했다. 음성치료로 호 흡변수의 개선을 보였고 이 시점이 술후 3 개월이란 점에서 갑상 선 수술 영향으로 수술 후 3 개월까지도 호흡기능이 불안전하다 고해석된다.

Stojadinovic et al.(2002)에서는 갑상선절제술을 받은 50명(남: 여, 10:40)을 대상으로 술전-술후1주-술후3개월에 공기역학 검 사를 살펴보았다, 발성역치가 시간에 따라 차이를 보였고 술후 3 개월에 최대치를 보였으나 수술범위(엽절제 vs. 전절제)에 따 른 차이는 없었다. 주관적 후두 육안소견이 정상적일지라도 객 관적인 음성검사 변수와 불협치하는 경우가 $33 \%$ 정도로 높기 때문에 환자의 발성장애를 생리적학으로 이해하는 것이 무엇 보다 중요하다고 강조했다. 참고로, 본 선행연구에서 술후3개 월에 참여자가 4명 줄어 46명만 검사를 받았다. 이는 반복측정 분산분석을 적용할 때 결측값으로 인해 술전부터 46 명만 통계 검증에 투입되므로 본 결과는 50 명이 아닌 46 명의 결과로 해석 해야 한다.

Solomon et al.(2012)에서는 전신마취 때 기도삽관을 따른 부 작용을 확인하기 위해서 갑상선절제술 받은 80명(남:여, 33:47) 과 대조군으로 경부이외 수술(nonneck surgery)을 받은 16명(남:
여, 5:11)을 대상으로 술전-술후2주-술후3개월의 공기역학 검사 결과, 두 집단 간 발성역치압력만이 유의미한 차이를 보였고 이 는 집단과 기본주파수 요소에서도 차이를 보였다. 일반적으로 술 후 음성에 문제가 있다면 발성역치 수치가 상승할 것이고 하 강한다면 노력을 적게 들이면서 건강하게 발성한다고 해석되 지만, 일반적으로 갑상선 수술 환자들은 술후 음도 하강 증상을 겪게 되므로 본 선행연구 결과의 발성역치압력 하강은 건강한 발성이라서 하강했다고 보기보다 음도 하강에 따른 결과로 판 단하는 것이 타당해 보인다.

Maeda et al.(2013)에서는 110명(남:여, 19:91)의 갑상선절제술 환자군과 대조군으로 이하선 절제술을 받은 13 명의 환자를 대 상으로 술전-술직후-술후1개월-술후3개월에 공기역학 검사를 실시하였다. 전절제군이 수술직후 최대연장발성시간은 줄었고 특히 엽절제군보다 최대연장발성시간과 평균호기류율이 유의미 하게 줄었다. 또한 술직후 중심경부절제술(central neck dissection, $\mathrm{CND}$ )을 실시하지 않은 환자보다 경부절제술을 같이 시행한 갑 상선절제술 환자의 최대연장발성지속시간이 더 길었으나 술후 1 개월에는 통계적차이가 없었다. 또한 경부절제술을 같이 받은 전절제술(total thyroidectomy with CND) 환자는 수술 후 음질 악 화 영향이 뚜렷했으며 이는 정맥과 림프액 배수의 장애로 인한 후두의 부종 때문이라고 보았고 이런 변화는 일시적으로 혹은 몇 주 후 없어진다고 보고했다.

Yilmaz et al.(2016)에서 44명(남:여, 9:35)의 갑상선절제술 환 자를 대상으로 술전-술후1개월-술후3개월 간 검사결과, 최대모 음연장발성시간과 마찰음/s/ 발성시간의 유의미한 차이를 보고 했고, 술후1개월에 가장 낮은 수치였고 술후3개월에서 상승했 다. 본 선행연구 연구자들은 이런 변화가 성별, 나이, 수술 기법 간 차이가 아니라 종양(tumor)의 종류(양성 benign vs. 악성malignant) 간 차이라고 보았으며 악성 종양 환자에게는 목소리 변화 정보 를 수술 전에 미리 설명해야 한다고 주장했다.

이상의 선행연구에서는 갑상선절제술을 받은 환자들의 음질 변화를 바탕에 두고 공기역학적 변화를 살펴본 것으로 모든 선 행연구에서 남녀를 합산하여 통계 검증을 실시하였기에 성별 에 따른 근본적인 호흡기능 차이를 간과했다고 말할 수 있다. 본 연구는 갑상선절제술 받은 여성 환자를 대상으로 공기역학 검사를 진행하여 수술 후 호흡 개선이 되는 시기를 살펴보고 임 상에 활용하고자 한다.

\section{2. 연구 대상자 및 방법}

\section{1. 연구대상자}

본 연구대상자는 2015년 갑상선절제술 환자의 음향적 분석 을 발표한 선행연구(Kang \& Koo, 2015)에 참여한 대상자들이며 본 연구에서는 발표되지 않은 여성군의 공기역학 검사결과 자 료를 분석하였다.

2014년 5월부터 2015년 7월까지 본원에서 갑상선 유두암 (papillary thyroid carcinoma, PTC)으로 진단받고 갑상선절제술 을 받은 환자를 대상으로, 수술 1주일 전(PRE), 수술 후 1 개월 
(P1) 및 수술 후 3개월(P3)에 공기역학 검사를 실시하였다. 모든 공 기역학 검사 전에 이비인후과 전문의가 비강후두내시경(Olympus, OTV S7Pro, USA)을 사용하여 환자의 성대상태를 확인하였고, 성대마비, 보청기 착용, 항우울증 복용, 호흡기 질환, 뇌졸중 병 력 및 임신 대상자를 제외시켜 최종 여성 34 명을 선별하였다. 전체 대상자의 연령범위는 21-76세, 평균( \pm 표준편차) 47.3세( \pm 14.8$)$, 중위수 45.5세이고 수술병변은 전절제술(total thyroidectomy, TT) 20건, 좌측 엽절제(left lobectomy, Lt. TL) 6건, 우측 엽절제(Right lobectomy, Rt. TL) 8건이었다(표 1 참조).

모든 수술은 동일한 전문의 1 인에 의해서 이루어졌으며 본 연구는 충남대학교병원 임상시험심사위원회의 승인을 받아 진 행되었다(CNUH 2014 10-02 2-001).

표 1. 대상자 정보

Table 1. Subject information

\begin{tabular}{l|c}
\hline Subjects, no & 34 (all female) \\
\hline Diagnosis (\% of total) & PTC (100\%) \\
\hline Age, yrs. & $21-76$ \\
\hline Range & $47.3 \pm 14.8$ \\
\hline Mean \pm SD & 45.5 \\
\hline Median & 20 \\
\hline Extent of thyroidectomy & 6 \\
\hline TT & 8 \\
\hline Lt. TL &
\end{tabular}

PTC, papillary thyroid carcinoma; TT, total thyroidectomy; Lt. TL, left thyroid-lobectomy; Rt. TL, right thyroid-lobectomy.

\section{2. 공기역학 검사 및 통계분석}

공기역학 검사는 병원 내 방음문이 설치된 조용한 방에서 실시 하였다. 검사장비는 Phonatory Aerodynamic System (PAS model 6600, KayPentax, USA)를 사용하여 임상에서 기본적으로 널리 평가되는 3 과제를 평가했다; (1) 호흡-발성에 활용될 수 있는 잠 재된 최대한의 공기량을 측정하는 폐활량 과제(vital capacity, VTCP), (2) 모음/아/를 최대한 지속하여 공기흐름, 음압, 음도를 측정하는 최대모음연장발성 과제(maximum sustained phonation, $\mathrm{MXPH}),(3)$ 파열음/ $\mathrm{pa} /$ 를 연속 발성하여 발성효율역치를 확인 하는 과제(voicing efficiency threshold, VOFT).

검사의 신뢰성을 높이기 위해 4시간마다 1.0 Liter syringe를 사용하여 $\pm 1 \%$ 가 넘지 않도록 보정작업을 실시하였고 모든 과 제 수행 시 환자에게 평상시 편안한 발성을 하도록 요구했다. 검사자의 1 회 설명과 시연, 환자의 1 회 연습 이후 녹음을 진행
하였다. 또한 공기 누출을 막기 위해 검사용 마스크가 안면부에 완전 밀착되도록 모든 과제시 검사자가 마스크 상단을 손으로 눌러주었다. VTCP 과제는 마스크를 입에 밀착시킨 후에 구강 으로 최대 흡기를 한 후 최대한 강하고 길게 구강으로 공기를 뱉도록 요구하였다. 첫 수행 후에 마스크를 밀착시킨 상태를 유 지하면서 15 초 정도 시간차를 두고 비강으로 호흡을 편하게 조 절하여 안정화시킨 후에 다시 두 번째 수행을 동일하게 실시하 였다. 두 수행 중 폐활량 수치가 더 큰 것을 결과로 기록하였다. $\mathrm{MXPH}$ 과제는 마스크를 밀착한 상태에서 구강으로 최대한 흡 기를 한 후 편안한 음도와 강도로 모음/아/를 길게 발성하도록 요구하였다. VOFT 과제에서는 한숨에 /파/ 연속 발성 7번을 유 도하였고 이중 중간 5 개를 선택하여 분석하였다. 발성이 일정 한 간격이 되도록, 발성하는 동안 1 초에 1 번꼴로 환자 등을 손 으로 가볍게 두들겨주는 신호를 주었다. 분석 변수는 PAS에서 제공하는 29 개의 모든 변수를 선택하였고 변수의 한글명은 선 행연구를 따랐으며(Kang et al., 2016), 부록 1에 변수 목록을 제 시하였다.

통계는 SPSS $19.0^{\mathrm{TM}}(\mathrm{SPSS}$, Chicago, IL)를 사용하여 집단 내 (술전-술후1-술후3의 시간별 측정)과 집단 간(수술범위)을 2 요 인으로 한 혼합분산분석(two-way mixed ANOVA)을 적용하였 다. 구형성 가정을 충족하지 못할 경우는 엡실론 값이 1 에 가까 운 가정의 요인 값으로 유의성을 확인하였다. 주효과와 상호작 용이 유의할 경우는 Bonferroni 사후검정을 실시하였다.

\section{3. 결과}

34 명 여성 환자를 대상으로 29개 공기역학 변수에 대해서 반 복측정 분산분석으로 시간에 따른 변화(PRE-P1-P3)를 살펴본 결과, VTCP 과제에서 최고호기류율[peak expiratory airflow, $F(1.60,49.61)=6.830, p=0.004]$ 변수가 유의미했고, VOFT 과제에 서 평균음도[mean pitch, $F(2.62)=10.64, p<0.000]$, 호기류지속시 간[expiratory airflow duration, $F(2.62)=8.59, p=0.001]$, 호기량 [expiratory volume, $F(2.62)=4.27, p=0.018$ ] 변수가 통계적으로 유의미한 차이를 보였다. 시간 요인의 대응비교에서 최고호기 류율와 평균음도 변수는 PRE-P1, PRE-P3 간 차이를 보였고, 호 기류지속시간과 호기량 변수는 PRE-P3, P1-P3 간 차이를 보였 다. 시간과 수술 범위의 교호작용 효과는 VOFT 과제의 호기량 [expiratory volume, $F(2.62)=3.01, p=0.024$ ] 변수만 유의하였다.

전체 변수의 기술통계량과 통계검정은 부록 2에 제시하였고

표 2. 유의미한 공기역학 변수의 평균(표준편차)

Table 2. Mean and SD of significant aerodynamic parameters

\begin{tabular}{|c|c|c|c|c|c|}
\hline \multirow{2}{*}{ Parameter } & \multicolumn{3}{|c|}{$\operatorname{Mean}(S D)$} & \multirow{2}{*}{$p$-value ${ }^{\$}$} & \multirow{2}{*}{ Group paired } \\
\hline & PRE & P1 & P3 & & \\
\hline Peak expiratory airflow & $4.79(2.09)$ & $3.64(1.55)$ & $3.71(1.37)$ & $0.004^{* *}$ & \multirow{2}{*}{$\begin{array}{l}\text { PRE-P1 } \\
\text { PRE-P3 }\end{array}$} \\
\hline Mean pitch & $218.20(28.01)$ & $199.80(33.67)$ & $202.41(29.15)$ & $<0.000^{* *}$ & \\
\hline Expiratory airflow duration & $0.76(0.25)$ & $0.80(0.27)$ & $0.98(0.29)$ & $0.001^{* *}$ & \multirow{2}{*}{$\begin{array}{c}\text { PRE-P3 } \\
\text { P1-P3 }\end{array}$} \\
\hline Expiratory volume & $0.10(0.06)$ & $0.12(0.09)$ & $0.14(0.07)$ & $0.018^{*}$ & \\
\hline
\end{tabular}

$\$$ two-way mixed ANOVA.

${ }^{*} p<0.05,{ }^{* *} p<0.01$. 
유의미한 변수만을 추려서 표 2에 정리하였다. 시간대별 평균 은 그림 1에 도식화 하였고 호기량 변수는 교호작용이 있었기 에 수술범위에 따른 시간대별 평균으로 제시하였다.
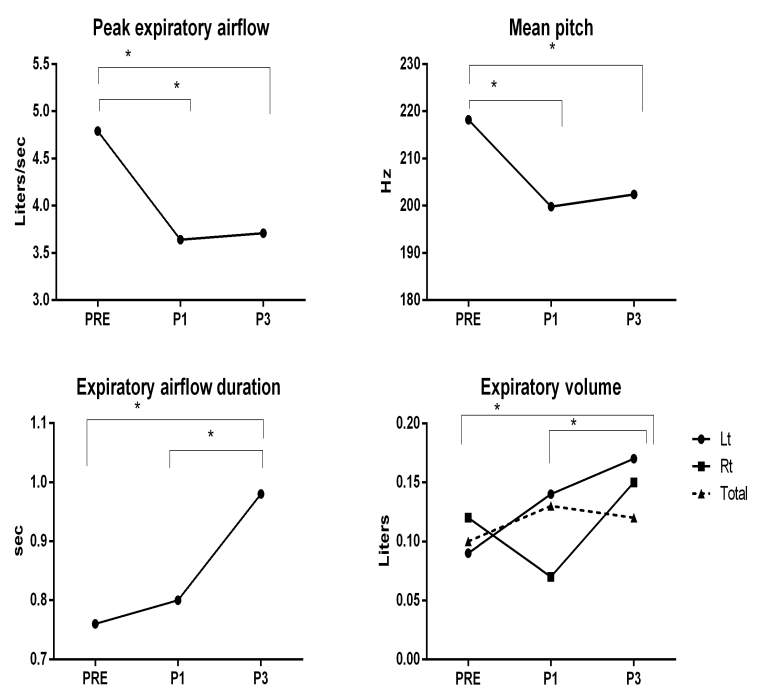

그림 1. 여성군의 유의미한 공기역학 변수

Figure 1. Significant aerodynamic parameters in female group

\section{4. 논의 및 결론}

갑상선절제술을 받은 여성 환자를 대상으로 수술 전부터 수 술 후 3 개월까지 공기역학 검사변수를 추적 조사하였다. 시간 에 따라 최고호기류율, 평균음도, 호기류지속시간, 호기량 변수 가 차이를 보였고, 이 중 호기량 변수는 시간과 수술범위의 교 호작용이 있었다.

최고호기류율은 초당 공기량을 의미하며 PAS 검사 때 그래 프 피크가 올라가는 것으로 실시간 확인이 가능하다. 최고호기 류율의 피크 값은 호흡근력(muscle power)의 반영이다. 술후1개 월에 가장 낮은 수치를 보였고 술후3개월에 회복세를 보였다. 하지만 회복수치는 술전 측정치에는 도달하지 못하였다. VTCP 과제의 폐활량 차이가 없었기 때문에 이는 수술전후 폐활량의 차이는 없지만 호흡근력은 술후3개월까지도 수술 전 만큼 회복 하지 않았다고 해석해야 한다. Lee et al.(2015)의 연구에서도 수 술 후 3 개월에 호흡훈련을 하여 호흡 변수의 호전을 확인한 점 을 미루어볼 때 갑상선 수술환자 특히, 여성군의 경우에는 빠른 재활을 위해 수술 후 호흡훈련을 집중적으로 하는 음성치료가 제공될 필요가 있다고 생각한다.

평균음도는 술전이 가장 높았고 술후1개월에 가장 낮았다가 술후3개월에 상승세를 보였다. 본 평균음도 변수는 VOFT 과제 의 음도를 의미하는데 이는/파/ 연속 발성에서 음도를 측정한 것이다. MXPH 과제인 모음/아/ 연장발성에서의 평균음도는 통 계적으로 차이가 없었다. 이 두 가지 다른 과제 수행을 놓고 음 도를 살펴볼 때, 갑상선절제술을 받은 여성 환자들은 연속발성 보다 끊어진 발성 즉 발성을 음절 단위로 끊어지게 하는 조음을
할 때 음도 하강이 더 잘 표현된다는 점이고 이는 일상 발화에 서도 관찰될 수 있다. 또한 수술범위로 세부적으로 살펴보면 엽 절제군보다 전절제군의 술후1개월에 $180 \mathrm{~Hz}$ 대로 수치하강이 가장 컸고 술후 3 개월에 회복 폭도 $190 \mathrm{~Hz}$ 로 엽절제군보다 다소 낮았다. 이는 엽절제군보다 전절제군이 목 앞쪽을 절개하여 피 대근 손상으로 더 큰 점과 상관 있다고 보여진다. 또한 VOFT 과 제의 음도이므로 앞서 언급한 최고호기류율 피크 점과 연관지 어 생각해보면, 호기를 균등하게 내뱉어주는 호흡근력의 약화 로 VOFT 과제의 음도가 $\mathrm{MXPH}$ 과제의 음도와 달리 차이를 보 였다고 생각한다.

호기류지속시간과 호기량은 모두 VOFT 과제 변수로 술전보 다 술후3개월에 더 높은 수치를 보였다. 본 연구팀이 소속된 병 원에서는 갑상선 수술 사전교육으로 폐 기능 회복을 돕기 위해 수술 후 걷기운동을 권고하는데 많은 환자들이 꾸준히 운동을 하는 편이고 이런 가벼운 걷기운동이 폐활량 증가 및 호기류지 속시간 상승에 반영되었다고 생각한다.

추가적으로 본 연구에서는 유의미한 결과를 보이지 않았지 만 공기역학 검사에서 항상 언급되는 최대연장발성시간 변수 에 대해서 연구팀의 생각을 정리해 보면 다음과 같다. 수술전후 최대연장발성시간의 변화를 보인 Maeda et al.(2013), Shin et al.(2014), Yilmaz et al.(2016)의 선행연구와 달리 본 연구에서는 최대연장발성시간의 변화는 통계적으로 유의미하지 않았다. 최대연장발성시간을 볼 때 음성강도를 확인하여 어떤 강도에 서 얼마나 발성 길이를 생성했는지 확인해야 정확한 해석을 할 수 있다. 본 연구의 변수 중 평균음압(mean sound pressure level) 변수가 최대연장발성시간 과제를 수행할 때의 강도 변수이고 이 변수 또한 수술 전후 차이가 없었다. 언급한 선행연구에서는 최대연장발성지속시간에 관련되는 강도 수치가 모두 누락되어 있어 정확한 해석을 할 수 없지만 본 연구 결과에서는 수술 전 후 강도 및 최대연장발성지속시간의 변화는 통계학적으로 차 이가 없었다. 이는 수술이후 성대의 부종으로 최대발성지속시 간이 감소한다는 선행연구와 대치된다.

본 연구의 한계점은 수술 후 3 개월까지 추적 조사를 하였으 나 더 길게 조사기간을 잡지 못한 점과 환자들의 수술 후 생활 개선을 통한 호흡계통 향상 정도를 파악하지 못한 점이다. 암 진단과 수술이라는 절차를 겪으면서 환자들은 삶의 목표와 생 활습관을 긍정적으로 개선하는 경우가 많았고 이런 긍정적 삶 의 자세가 호흡에 어떤 영향을 주는지도 향후 객관적으로 확인 할 수 있는 연구가 필요할 것으로 생각한다.

본 연구는 갑상선절제술을 받은 여성 환자를 대상으로 공기 역학 검사를 수술 전부터 수술 후 3 개월까지 추적 조사한 것으 로 최고호기류율과 평균음도 변수의 차이를 확인하였고 이는 특별히 갑상선 수술 후 여성 환자에게 호흡훈련의 필요성이 있 음을 확인했다. 또한 수술 후 호기류지속시간과 호기량 변수의 개선을 보였는데 이는 수술 후 긍정적 생활습관 반영과 관련성 을 시사한다. 


\section{References}

Choi, S. H. (2010). Dignosis and management of voice change after thyroid surgery. Journal of Korean Thyroid Association, 3(1), 8-14.

Hong, K. H. (2014). Post-thyroidectomy syndrome. Korean Journal of Otorhinolaryngology-Head and Neck Surgery, 57(5), 297-303.

Kang, Y. A. \& Koo, B. S. (2015). Acoustic analysis of voice change according to extent of thyroidectomy. Phonetics and Speech Sciences, 7(4), 77-83.

Kang, Y. A., Chang, J. W., \& Koo, B. S. (2016). Aerodynamic features in patients with vocal polyps before \& after laryngomicrosurgery. Phonetics and Speech Sciences, 8(3), 39-49.

Lee, C. Y., An, S. Y., Chang, H., Jeong, H. S., \& Son, H. Y. (2015). Aerodynamic features and voice therapy interventions of functional voice disorder after thyroidectomy. Journal of the Korean Society of Larynoglogy, Phoniatrics and Logopedics, 26(1), 25-33.

Maeda, T., Saito, M., Otsuki, N., Morimoto, K., Takahashi, M., Lwaki, S., Inoue, H., Tomoda, C., ․ Nibu, K. I. (2013). Voice quality after surgical treatment for thyroid cancer. Thyroid, 23(7), 847-853.

Park, J. H., \& Do, Y. N. (2015). Pathogenesis of the postthyroidectomy dysphonia. Journal of the Korean Society of Larynoglogy, Phoniatrics and Logopedics, 26(1), 16-20.

Shin, Y. J., Hong, K. H., Hong, Y. T., Oh, J. S., Yoon, Y. S., \& Lee, H. D. (2014). Aerodynamic analysis of voice in patients with thyroidectomy. Journal of Korean Thyroid Association, 7(1), 77-82.

Solomon, N. P., Helou, L. B., Makashay, M. J., \& Stojadinovic, A. (2012). Aerodynamic evaluation of the postthyroidectomy voice. Journal of Voice, 26(4), 454-461.

Stojadinovic, A., Shaha, A. R., Orlikoff, R. F., Nissan, A., Kornak, M. F., Singh, B., Boyle J. O., ․ Kraus, D. H. (2002). Prospective functional voice assessment in patients undergoing thyroid surgery. Annals of Surgery, 236(6), 823-832.

Yi, K. H., Lee, E. K., Kang, H. C., Koh, Y., Kim, S. W., Kim, I. J., Na, D. G., ‥ Rho, Y. S. (2016). 2016 revised Korean thyroid association management guidelines for patients with thyroid nodules and thyroid cancer. International Journal of Thyroidology, 9(2), 59-126

Yilmaz, B., Bakir, S., Yilmaz, E. E., Sengul, E., Uslukaya, O., Gul, A., Emre, F. O., \& Topcu, I. (2016). An analysis on aerodynamic and acoustic changes after thyroidectomy. International Surgery, 101(5-6), 233-240
- 강영애(Young Ae Kang) 제 1저자

충남대학교병원 이비인후과 음성언어치료사

충남대학교 의학연구소 객원연구원

대전광역시 중구 문화로 282

관심분야: 음성장애, 신경 말-언어장애, 장애음성분석

연락처 : kangyoungae1@naver.com

\section{- 권인선(In Sun Kwon)}

충남대학교병원 임상시험센터 통계 박사

대전광역시 중구 문화로 282

관심분야 : 의학통계

연락처 : kiss95@cunh.co.kr

\section{- 원호륜(Ho Ryun Won)}

충남대학교병원 이비인후과 교수

대전광역시 중구 문화로 282

관심분야 : 갑상선암, 후두질환, 음성장애

연락처 : hryun83@cnuh.co.kr

\section{- 장재원(Jae Won Chang)}

충남대학교병원 이비인후과 교수

대전광역시 중구 문화로 282

관심분야 : 갑상선암, 후두질환, 음성장애

연락처 : strive1005@cnuh.co.kr

- 구본석(Bon Seok Koo) 교신저자

충남대학교병원 이비인후과 교수

대전광역시 중구 문화로 282

관심분야 : 갑상선암, 후두질환, 음성장애

연락처 : bskoo515@cnu.ac.kr 
부록 1. 29개의 PAS 분석변수 목록

\begin{tabular}{|c|c|c|c|}
\hline Task & Parameter (English) & Parameter (Korean) & Unit \\
\hline \multirow{3}{*}{ VTCP } & Expiratory airflow duration & 호기지속시간 & sec \\
\hline & Peak expiratory airflow & 최고호기류율 & Liters/sec \\
\hline & Expiratory volume & 호기량 & Liters \\
\hline \multirow{10}{*}{$\mathrm{MXPH}$} & Maximum sound pressure level & 최대음압 & $\mathrm{dB}$ \\
\hline & Minimum sound pressure level & 최소음압 & $\mathrm{dB}$ \\
\hline & Mean sound pressure level & 평균음압 & $\mathrm{dB}$ \\
\hline & Sound pressure level range & 음압범위 & $\mathrm{dB}$ \\
\hline & Mean sound pressure level during voicing & 발성시 평균음압 & $\mathrm{dB}$ \\
\hline & Mean pitch & 평균음도 & $\mathrm{Hz}$ \\
\hline & Phonation time & 최대연장발성시간 & sec \\
\hline & Peak expiratory airflow & 최고호기류율 & Liters/sec \\
\hline & Mean expiratory airflow & 평균호기류율 & Liters/sec \\
\hline & Expiratory volume & 호기량 & Liters \\
\hline \multirow{16}{*}{ VOFT } & Maximum sound pressure level & 최대음압 & $\mathrm{dB}$ \\
\hline & Mean sound pressure level & 평균음압 & $\mathrm{dB}$ \\
\hline & Mean sound pressure level during voicing & 발성시 평균음압 & $\mathrm{dB}$ \\
\hline & Mean pitch & 평균음도 & $\mathrm{Hz}$ \\
\hline & Pitch range & 음도범위 & $\mathrm{Hz}$ \\
\hline & Expiratory airflow duration & 호기류지속시간 & $\sec$ \\
\hline & Peak air pressure & 최고성문하압 & $\mathrm{cmH}_{2} \mathrm{O}$ \\
\hline & Mean peak air pressure & 평균성문하압 & $\mathrm{cmH}_{2} \mathrm{O}$ \\
\hline & Peak expiratory airflow & 최고 호기류율 & Liters/sec \\
\hline & Target airflow & 표적 호기류율 & Liters/sec \\
\hline & Expiratory volume & 호기량 & Liters \\
\hline & Mean airflow during voicing & 발성시 평균호기류율 & Liters/s \\
\hline & Aerodynamic power & 공기역학력 & watts \\
\hline & Aerodynamic resistance & 공기역학저항 & $\mathrm{cm} \mathrm{H}_{2} \mathrm{O}$ \\
\hline & Acoustic Ohms & 음향저항 & dyne $\mathrm{sec} / \mathrm{cm}^{5}$ \\
\hline & Aerodynamic efficiency & 공기역학효율 & p.p.m \\
\hline
\end{tabular}

PAS, phonatory aerodynamic system; VTCP, vital capacity; MXPH, maximum sustained phonation; VOFT, voicing efficiency. 
부록 2. 공기역학 검사변수의 기술통계량 (평균, 표준편차)과 이원혼합분산분석 결과

\begin{tabular}{|c|c|c|c|c|c|c|c|c|c|c|c|c|}
\hline \multirow{3}{*}{ Task } & \multirow{3}{*}{ Parameters } & \multicolumn{9}{|c|}{ Mean $\pm S D$} & \multicolumn{2}{|c|}{$p$-value $\$$} \\
\hline & & \multicolumn{3}{|c|}{ Lt. TL } & \multicolumn{3}{|c|}{ Rt. TL } & \multicolumn{3}{|c|}{ TT } & \multirow[b]{2}{*}{ Time } & \multirow{2}{*}{$\begin{array}{r}\text { Time } \\
\text { by sur- } \\
\text { gery }\end{array}$} \\
\hline & & PRE & P1 & P3 & PRE & P1 & P3 & PRE & $\mathrm{P} 1$ & P3 & & \\
\hline \multirow{3}{*}{$\begin{array}{l}\mathrm{V} \\
\mathrm{T} \\
\mathrm{C} \\
\mathrm{P}\end{array}$} & $\begin{array}{l}\text { Expiratory } \\
\text { airflow duration }\end{array}$ & $2.50 \pm 0.91$ & $2.49 \pm 0.42$ & $3.11 \pm 0.25$ & $2.73 \pm 0.75$ & $3.02 \pm 0.73$ & $3.09 \pm 0.48$ & $2.51 \pm 0.96$ & $2.63 \pm 0.69$ & $2.51 \pm 0.64$ & 0.229 & 0.481 \\
\hline & $\begin{array}{l}\text { Peak expiratory } \\
\text { airflow }\end{array}$ & $4.99 \pm 2.20$ & $4.12 \pm 1.62$ & $3.55 \pm 1.44$ & $4.96 \pm 2.62$ & $3.56 \pm 1.73$ & $4.12 \pm 1.27$ & $4.66 \pm 1.93$ & $3.53 \pm 1.52$ & $3.59 \pm 1.43$ & $0.004^{*}$ & 0.807 \\
\hline & \begin{tabular}{|l|} 
Expiratory \\
volume
\end{tabular} & $2.40 \pm 0.65$ & $2.31 \pm 0.65$ & $2.29 \pm 0.65$ & $2.66 \pm 0.79$ & $2.32 \pm 0.67$ & $2.54 \pm 0.42$ & $2.57 \pm 0.63$ & $2.39 \pm 0.54$ & $2.44 \pm 0.69$ & 1.929 & 0.892 \\
\hline \multirow{10}{*}{$\begin{array}{l}\mathrm{M} \\
\mathrm{X} \\
\mathrm{P} \\
\mathrm{H}\end{array}$} & $\begin{array}{l}\text { Maximum sound } \\
\text { pressure level }\end{array}$ & $83.17 \pm 3.60$ & $87.70 \pm 7.71$ & $85.17 \pm 3.41$ & $87.67 \pm 5.39$ & $84.87 \pm 6.15$ & $83.27 \pm 3.60$ & $88.82 \pm 6.21$ & $87.47 \pm 6.60$ & $87.61 \pm 6.83$ & 0.474 & 0.168 \\
\hline & $\begin{array}{l}\text { Minimum sound } \\
\text { pressure level }\end{array}$ & $57.15 \pm 12.33$ & $58.71 \pm 13.95$ & $57.61 \pm 10.39$ & $64.65 \pm 5.76$ & $61.94 \pm 8.02$ & $62.93 \pm 2.98$ & $47.77 \pm 14.21$ & $60.75 \pm 11.20$ & $57.71 \pm 12.79$ & 0.401 & 0.121 \\
\hline & $\begin{array}{l}\text { Mean sound } \\
\text { pressure level }\end{array}$ & $78.56 \pm 5.03$ & $80.96 \pm 6.81$ & $80.54 \pm 2.75$ & $82.05 \pm 4.86$ & $79.18 \pm 4.28$ & $78.45 \pm 3.23$ & $83.20 \pm 6.87$ & $82.15 \pm 6.49$ & $81.99 \pm 6.89$ & 0.668 & 0.381 \\
\hline & \begin{tabular}{|l} 
Sound pressure \\
level range
\end{tabular} & $26.02 \pm 14.23$ & $28.98 \pm 12.81$ & $27.55 \pm 12.26$ & $23.01 \pm 7.40$ & $22.93 \pm 8.87$ & $20.34 \pm 5.08$ & $41.05 \pm 14.04$ & $26.72 \pm 12.76$ & $29.90 \pm 92.21$ & 0.311 & 0.070 \\
\hline & \begin{tabular}{|l} 
Mean sound \\
pressure level \\
during voicing
\end{tabular} & $78.68 \pm 4.98$ & $81.21 \pm 6.66$ & $79.36 \pm 3.58$ & $82.08 \pm 4.84$ & $79.19 \pm 4.29$ & $82.65 \pm 5.32$ & $83.59 \pm 6.94$ & $82.22 \pm 6.53$ & $81.95 \pm 5.89$ & 0.849 & 0.308 \\
\hline & Mean pitch & $213.12 \pm 32.09$ & $214.52 \pm 24.69$ & $199.29 \pm 19.20$ & $227.41 \pm 25.16$ & $212.71 \pm 30.0$ & $214.08 \pm 31.47$ & $206.31 \pm 28.76$ & $196.07 \pm 30.46$ & $198.68 \pm 30.64$ & 0.164 & 0.729 \\
\hline & Phonation time & \begin{tabular}{|l|l|}
$15.57 \pm 5.98$ \\
\end{tabular} & \begin{tabular}{|l|}
$14.57 \pm 5.37$ \\
\end{tabular} & $15.05 \pm 3.57$ & $19.97 \pm 5.12$ & $20.15 \pm 3.48$ & \begin{tabular}{|l|l|}
$20.16 \pm 4.00$ \\
\end{tabular} & $18.87 \pm 5.35$ & $16.12 \pm 5.94$ & $16.47 \pm 5.05$ & 0.458 & 0.640 \\
\hline & $\begin{array}{l}\text { Peak expiratory } \\
\text { airflow }\end{array}$ & $0.23 \pm 0.06$ & $0.26 \pm 0.10$ & $0.22 \pm 0.08$ & $0.20 \pm 0.10$ & $0.20 \pm 0.09$ & $0.19 \pm 0.05$ & $0.21 \pm 0.10$ & $0.28 \pm 0.18$ & $0.24 \pm 0.15$ & 0.561 & 0.922 \\
\hline & $\begin{array}{l}\text { Mean expiratory } \\
\text { airflow }\end{array}$ & $0.13 \pm 0.03$ & $0.16 \pm 0.05$ & $0.13 \pm 0.03$ & $0.11 \pm 0.08$ & $0.10 \pm 0.04$ & $0.10 \pm 0.04$ & $0.10 \pm 0.05$ & $0.13 \pm 0.07$ & $0.13 \pm 0.07$ & 0.481 & 0.368 \\
\hline & \begin{tabular}{|l} 
Expiratory \\
volume
\end{tabular} & $2.00 \pm 0.58$ & $2.19 \pm 0.62$ & $1.89 \pm 0.37$ & $1.94 \pm 0.93$ & $1.89 \pm 0.63$ & $2.05 \pm 0.63$ & $1.93 \pm 0.88$ & $1.94 \pm 0.78$ & $1.99 \pm 0.76$ & 0.940 & 0.802 \\
\hline \multirow{16}{*}{$\begin{array}{l}\mathrm{V} \\
\mathrm{O} \\
\mathrm{F} \\
\mathrm{T}\end{array}$} & $\begin{array}{l}\text { Maximum sound } \\
\text { pressure level }\end{array}$ & $81.47 \pm 3.89$ & $83.87 \pm 4.14$ & $82.13 \pm 2.78$ & $85.08 \pm 5.48$ & $84.05 \pm 5.54$ & $85.36 \pm 5.56$ & $83.11 \pm 6.85$ & $83.36 \pm 5.31$ & $84.50 \pm 6.12$ & 0.748 & 0.715 \\
\hline & \begin{tabular}{|l} 
Mean sound \\
pressure level
\end{tabular} & $79.98 \pm 3.62$ & $82.18 \pm 4.17$ & $79.36 \pm 3.56$ & $82.85 \pm 5.54$ & $81.19 \pm 6.91$ & $82.65 \pm 5.32$ & $80.99 \pm 6.57$ & $80.40 \pm 5.17$ & $81.95 \pm 5.88$ & 0.998 & 0.465 \\
\hline & \begin{tabular}{|l|} 
Mean sound \\
pressure level \\
during voicing
\end{tabular} & $79.98 \pm 3.62$ & $82.18 \pm 4.17$ & $79.36 \pm 3.56$ & $82.85 \pm 5.54$ & $81.20 \pm 6.90$ & $82.65 \pm 5.32$ & $81.26 \pm 6.57$ & $80.42 \pm 5.17$ & $81.95 \pm 5.89$ & 0.998 & 0.466 \\
\hline & Mean pitch & $225.61 \pm 23.78$ & $213.88 \pm 19.93$ & $199.29 \pm 19.20$ & $232.94 \pm 25.36$ & $216.54 \pm 34.58$ & $214.08 \pm 31.47$ & $210.09 \pm 28.26$ & $188.88 \pm 33.43$ & $198.18 \pm 30.64$ & $<0.000^{* *}$ & 0.223 \\
\hline & Pitch range & $10.04 \pm 8.19$ & $10.87 \pm 7.09$ & $11.78 \pm 6.33$ & $10.00 \pm 4.65$ & $13.98 \pm 10.84$ & $15.93 \pm 10.33$ & $26.96 \pm 35.74$ & $21.83 \pm 25.59$ & $19.24 \pm 24.69$ & 1.00 & 0.846 \\
\hline & $\begin{array}{l}\text { Expiratory } \\
\text { airflow duration }\end{array}$ & $0.78 \pm 0.26$ & $0.92 \pm 0.25$ & $1.11 \pm 0.18$ & $0.79 \pm 0.27$ & $0.72 \pm 0.26$ & $1.11 \pm 0.31$ & $0.75 \pm 0.25$ & $0.80 \pm 0.27$ & $0.88 \pm 0.29$ & $0.001^{* *}$ & 0.262 \\
\hline & Peak air pressure & $7.76 \pm 2.68$ & $7.47 \pm 2.11$ & $7.63 \pm 1.89$ & $7.85 \pm 2.01$ & $8.67 \pm 1.77$ & $8.73 \pm 1.91$ & $8.09 \pm 3.73$ & $9.44 \pm 3.97$ & $9.20 \pm 3.39$ & 0.476 & 0.821 \\
\hline & $\begin{array}{l}\text { Mean peak air } \\
\text { pressure }\end{array}$ & $7.11 \pm 2.49$ & $6.54 \pm 2.03$ & $6.48 \pm 1.87$ & $7.18 \pm 1.72$ & $7.66 \pm 1.59$ & $7.78 \pm 2.08$ & $7.03 \pm 3.29$ & $8.38 \pm 3.61$ & $7.99 \pm 3.16$ & 0.690 & 0.542 \\
\hline & $\begin{array}{l}\text { Peak expiratory } \\
\text { airflow }\end{array}$ & $0.14 \pm 0.08$ & $0.18 \pm 0.03$ & $0.18 \pm 0.05$ & $0.20 \pm 0.10$ & $0.16 \pm 0.08$ & $0.18 \pm 0.09$ & $0.18 \pm 0.12$ & $0.22 \pm 0.15$ & $0.19 \pm 0.11$ & 0.766 & 0.227 \\
\hline & Target airflow & $0.13 \pm 0.07$ & $0.15 \pm 0.30$ & $0.15 \pm 0.05$ & $0.15 \pm 0.07$ & $0.10 \pm 0.05$ & $0.13 \pm 0.08$ & $0.14 \pm 0.09$ & $0.16 \pm 0.12$ & $0.14 \pm 0.08$ & 0.971 & 0.245 \\
\hline & \begin{tabular}{|l} 
Expiratory \\
volume
\end{tabular} & $0.09 \pm 0.03$ & $0.14 \pm 0.05$ & $0.17 \pm 0.07$ & $0.12 \pm 0.08$ & $0.07 \pm 0.33$ & $0.15 \pm 0.10$ & $0.10 \pm 0.07$ & $0.13 \pm 0.11$ & $0.12 \pm 0.06$ & $0.018^{*}$ & $0.024^{*}$ \\
\hline & $\begin{array}{l}\text { Mean airflow } \\
\text { during voicing }\end{array}$ & $0.12 \pm 0.07$ & $0.15 \pm 0.02$ & $0.14 \pm 0.05$ & $0.15 \pm 0.07$ & $0.10 \pm 0.05$ & $0.13 \pm 0.09$ & $0.13 \pm 0.09$ & $0.15 \pm 0.12$ & $0.14 \pm 0.08$ & 0.953 & 0.287 \\
\hline & \begin{tabular}{|l} 
Aerodynamic \\
power
\end{tabular} & $0.09 \pm 0.07$ & $0.10 \pm 0.04$ & $0.10 \pm 0.05$ & $0.10 \pm 0.61$ & $0.07 \pm 0.03$ & $0.11 \pm 0.09$ & $0.09 \pm 0.07$ & $0.14 \pm 0.12$ & $0.11 \pm 0.07$ & 0.823 & 0.298 \\
\hline & \begin{tabular}{|l} 
Aerodynamic \\
resistance
\end{tabular} & $78.49 \pm 68.58$ & $42.64 \pm 15.86$ & $43.97 \pm 8.89$ & $75.89 \pm 95.50$ & $94.13 \pm 64.79$ & $74.39 \pm 45.97$ & $74.02 \pm 50.97$ & $86.15 \pm 78.74$ & $73.21 \pm 59.21$ & 0.553 & 0.471 \\
\hline & Acoustic ohms & \begin{tabular}{|l|}
$80.04 \pm 69.94$ \\
\end{tabular} & $43.49 \pm 16.17$ & $44.84 \pm 9.07$ & $77.39 \pm 97.40$ & $95.99 \pm 66.07$ & \begin{tabular}{|l|l}
$75.87 \pm 46.88$ \\
\end{tabular} & $74.47 \pm 51.88$ & $87.85 \pm 80.30$ & $74.60 \pm 60.38$ & 0.553 & 0.471 \\
\hline & $\begin{array}{l}\text { Aerodynamic } \\
\text { efficiency }\end{array}$ & $315.75 \pm 295.52$ & $404.59 \pm 450.10$ & $985.53 \pm 164.40$ & $1,298.19 \pm 2,817.61$ & $820.90 \pm 1,255.90$ & $0788.67 \pm 114.81$ & $768.43 \pm 1,275.80$ & $358.40 \pm 432.27$ & $442.54 \pm 440.53$ & 0.287 & 0.781 \\
\hline
\end{tabular}

$\$$ two-way mixed ANOVA.

${ }^{*} p<0.05,{ }^{* *} p<0.01$.

VTCP, vital capacity; MXPH, maximum sustained phonation; VOFT, voicing efficiency; Lt. TL, left thyroid-lobectomy; Rt. TL, right thyroidlobectomy; TT, total thyroidectomy. 


\title{
갑상선절제술을 받은 여성 환자의 공기역학 검사변수 조사*
}

\author{
강 영 애 ${ }^{1} \cdot$ 권 인 선 ${ }^{2}$ 원 호 륜 ${ }^{1} \cdot$ 장 재 원 ${ }^{1}$ 구 본 석 ${ }^{1}$ \\ 1충남대학교병원 이비인후과, ${ }^{2}$ 충남대학교병원 임상시험센터
}

\section{국문초록}

갑상선 수술 후 음성변화를 보이는 경우가 흔하며 신경손상의 성대마비부터 심인성 음성장애까지 그 증상은 복합 적이고 다양하다. 대부분 자연적으로 회복을 보이지만 환자에게 회복시점에 대한 자세한 정보가 부족하다. 호흡은 음성을 만드는 동력이면서 동시에 후두 기능과 효율에 대한 조절자 역할을 하는데, 갑상선 암 수술의 전신마취 부 작용으로 호흡기능 부조화를 유발할 수 있다. 이에 본 연구에서는 갑상선 수술 전후 공기역학적 검사결과를 추적 하여 갑상선 수술 후 음성회복에 실제적이고 보완적인 정보를 제공하고자 한다. 2014년 5월부터 2015년 7월까지 갑 상선 유두암으로 진단받고 수술 받은 환자를 대상으로 술전 1 주일, 술후1개월, 술후 3 개월에 공기역학 검사를 실시 하였다. 성 대마비, 보청기 착용자, 항우울증약 복용자, 호흡기 질환자, 뇌졸중 병력자 및 임신 대상자는 제외시켜 최종 34 명을 대상자로 선정하였다. 공기역학 검사는 PAS 기계를 사용하였고 분석변수는 총 29 개이며, 시간요인에 따른 최고호기류율 $(p=0.004)$, 평균음도 $(p<0.01)$, 호기류지속시간 $(p=0.001)$, 호기량 $(p=0.018)$ 변수가 통계적으로 유의 미한 차이를 보였다. 이때 시간요인의 대응비교에서 최고호기류율과 평균음도 변수는 술전-술후1개월, 술전-술후3 개월 간 차이를 보였고, 호기류지속시간과 호기량 변수는 술전-술후 3 개월, 술후 1 개월-술후 3 개월 간 차이를 보였다. 시간과 수술범위의 교호작용 효과는 호기량 $(p=0.024)$ 변수에서만 유의하였다. 갑상선절제술을 받은 여성군에서 최고호기류율과 평균음도 변수의 차이가 있으며 이는 수술 후 호흡훈련의 필요성이 있으며 호기류지속시간과 호 기량 변수의 변화는 수술 후 긍정적 생활습관의 반영으로 여겨진다.

핵심어: 갑상선절제술, 공기역학 검사, 여성

\section{참고문헌}

강영애, 구본석(2015). 갑상선 수술범위에 따른 음성의 음향적 분 석. 말소리와 음성과학, 7(4), 77-83.

강영애, 장재원, 구본석(2016). 성대용종 환자의 후두미세수술 전

후 공기역학 변수 변화. 말소리와 음성과학, 8(3), 39-49.

박준희, 도남용(2015). 갑상선 절제술 후 발성 장애의 병인. 대한 후두음성언어의학회지, 26(1), 16-20.

신유정, 홍기환, 홍용태, 오정석, 윤연섭, 이현두(2014). 갑상선절 제술 환자 음성의 공기역학적 분석. 대한갑상선학회지, 7 (1), 77-82.

이가희, 이은경, 강호철, 고윤우, 김선욱, 김인주, 나동규, $\cdots$ 노영 수(2016). 2016 년 대한갑상선학회 갑상선결절 및 암 진료 권 고안 개정안. 대한갑상선학회지, 9(2), 59-126.

이창윤, 안수연, 장현, 정희석, 손희영 (2015). 갑상선 절제술 후기 능적 음성장애의 공기역학적 특징과 음성치료 중재. 대한후 두음성언어의학회지, 26(1), 25-33.
최승호(2010). 갑상선 수술 후 음성변화의 진단 및 치료. 대한갑 상선학회지, 3(1), 8-14.

홍기환(2014). 갑상선 수술 후 증후군. 대한이비인후과학회지, 57(5), 297-303.

* 이 연구는 충남대학교 학술연구진흥사업에 의해 지원되었음. 